\title{
PERENCANAAN DAN PENGENDALIAN PERSEDIAN BAHAN BAKU DENGAN MENGGUNAKAN METODE MATERIAL REQUIREMENT PLANNING
}

\author{
Riko Ervil $^{1}$, Rahul Mahendral ${ }^{2}$ \\ Program Studi Teknik Industri, Sekolah Tinggi Teknologi Industri Padang \\ Email:rikopdg01@gmail.com
}

\begin{abstract}
Abstrak: PT. Cahaya Murni Andalas Permai merupakan sebuah industri yang bergerak di bidang furniture, dengan permintaan lebih besar dari produksi. Permasalahan antara lain persedian bahan baku yang ada di gudang kadang tidak mencukupi kebutuhan produksi dan tidak ada jadwal pembelian bahan baku. Semua kegiatan perencanaan kebutuhan bahan baku pada PT. Cahaya Murni Andalas Permai harus ditentukan untuk meningkatkan kinerja perusahaan, untuk itu ditentukan perencanaan dan pengendalian bahan baku dengan menggunakan metode Material Requirement Planning (MRP). Tahapan MRP yang dilakukan antara lain : pembuatan Bill Of Material, pembuatan struktur produk, peramalan ( metode siklis dan linier ), Master Production Schedule (MPS), membuat kebutuhan bahan baku dengan menggunakan Lor For Lot. Perencanaan bahan baku yang dibutuhkan peramalan penjualan bulan berikutnya denggan menggunakan metode linier dengan nilai SEE terkecil 96,003. Hasil dan kesimpulan dengan menggunakan metode Material Requirement Planning (MRP) ini adalah jumlah permintaan meningkat dari tahun 2018 sebesar 20.930 unit dan pada tahun 2019 sebesar 21654 unit, maka dibutuhkan metode $M R P$ ini untuk merencanakan berapa kebutuhan bahan baku untuk 12 periode kedepannya dengan nilai tiap bulanya dapat ditentukan.
\end{abstract}

Kata Kunci: Bill Of Material, Peramalan, Material Requirement Planning dan Master Production Shedule

\begin{abstract}
Abstrac: PT. Cahaya Murni Andalas Permai is an industry engaged in furniture, with demand greater than production. Problems include the availability of raw materials in the warehouse sometimes not enough to meet the needs of production and there is no scheduled purchase of raw materials. All raw material needs planning activities in PT .Cahaya Murni Andalas Permai must be determined to improve company performance, for that purpose is determined planning by controlling raw materials by using the material requirement planning method. The stages of material requirement planning are carried out, among others, making bills of material, making product structures, forecasting (linier method and siklis method), master production schedules, making raw material needs by using lor for lot. Raw material planning needed forecasting sales the following month using a linier method with the smallest SEE value 96,003. The results and conclusions using this material requirement planning method are the number of requests increased from 2018 by 20.930 units and in 2019 by 21.654 units, this material needs planning method is needed to plan haw much raw material needs for 12 periods.
\end{abstract}

Keywords: Bill Of Material, Forecasting, Forecasting, Material Requirement Planning and Master Production Shedule

\section{PENDAHULUAN}

Dalam perencanaan dan pengendalian bahan baku PT. Cahaya Murni Andalas permaibergerak di bidang furniture yang menerima pesanan secara langsung dari rekanan perusahaan, oleh sebeb itu perusahaan dituntut agar bisa tepat waktu dalam proses produksi. Masalah yang sering terjadi dalam proses produksi adalah persedian bahan baku yang ada digudang terkadang tidak mencukupi. Misalnya kurangnya persedian bahan baku pada komponen BO misalnya pada komponen benang, per bulat, kawat lilit, steples cr, steples cl, per pinggir air vent dan plastic mika. Untuk mengantisipasi atau mencegah agar tidak terjadinya kelebihan atau kekurangan persedian bahan baku pada perusahaan, sehingga perlu adanya suatu metode yang dapat 
memberikan solusi permasalahan pada perusahaan khususnya dibidang persediaan bahan baku.

Batasan masalah dalam penelitian ini adalah penelitian dan pengumpulan data dilakukan pada proses assembling di PT. Cahaya Murni Andalas Permai, metode yang dipakai pada penelitian ini metode MRP, produk yang diteliti adalah jenis kasur single bed, dan metode peramalan yang digunakan adalah nilai SEE dari metode siklis dan linier. Tujuan yang ingin dicapai dalam penelitian ini adalah:

1. Merencanakan jadwal induk produksi (MPS) untuk tahun 2019

2. Menghitung perencanaan dan pengendalian bahan baku dengan menngunakann metode Material Requiremnt Planning.

\section{METODE PENELITIAN}

Data yang digunakan untuk penelitian ini adalah: persedian, waktu proses per-operasi kerja, lead time, jumlah komponen per unit, on hand, current inventory, allocated inventory, safety stock, jumlah mesin, jumlah shift, peramalan, pllaning horizon, dan jumlah yang produksi. Adapun jenis data yang digunakan dalam penelitian ini adalah data primer. Data yang dikumpulkan merupakan data-data yang diperoleh dari dokumen perusahaan dan hasil tanya jawab dengan pembimbing di lapangan. Untuk melakukan perencanaan dan pengendalian persedian bahan baku di PT. Cahaya Murni Andalas Permai dilakukan beberapa langkah-langkah pengolahan data. Teknik pengolahan dan analisa data pada penelitian ini dengan mengunakan metoda Material Requirement Planning dan Master Production Shedule

1. Melakukan Peramalan Kebutuhan Bahan Baku dengan menggunakan Standar Error of Estimate

Dari pola data yang terbentuk dipilih 2 metode peramalan dengan regresi linier sederhana. Metode yang digunakan pada pengolahan data adalah metode, Linier dan Siklis. Dapat dijelasakan pada berikut :

\section{a. Metode Linier}

Peramalan yang dilakukan dengan metode linier digunakan jika data historis atau masa lalu yang ada tersebut memiliki fluktuasi berupa garis lurus sepanjang periode waktu tertentu. Fungsi peramalan dengan metode ini adalah

$$
: y^{\prime}=a+b t
$$

\section{b. Metode Siklis}

Metode siklis melihat pola data masa lalu yang sifatnya trigonometri sepanjang periode yang merupakan fungsi dari sinus (sin) dan cosinus (cos). Fungsi peramalan dengan metode ini adalah :

$$
\begin{aligned}
& \quad y^{\prime}=a+b \cos \frac{2 \pi t}{n}+c \sin \frac{2 \pi t}{n} \\
& \text { c. Perhitungan Verifikasi peramalan }
\end{aligned}
$$

Metode peramalan selanjutnya dilakukan verifikasi terhadap metode peramalan. Hal ini digunakan untuk melihat apakah metode tersebut memang layak untuk digunakan dengan melihat sebaran datanya. Contoh perhitungan Verifikasi Metode Peramalan :

$$
\begin{gathered}
\text { MR rata }- \text { rata }=\frac{\text { Total } \mathrm{MR}}{\mathrm{N}} \\
\mathrm{BKA}=2,66 \times \mathrm{MR} \text { rata }- \text { rata } \\
\mathrm{BKB}=-2,66 \times \mathrm{MR} \text { rata }- \text { rata } \\
2 / 3 \mathrm{BKA}=2 / 3 \times \mathrm{BKA} \\
2 / 3 \mathrm{BKB}=2 / 3 \times \mathrm{BKB} \\
1 / 3 \mathrm{BKA}=1 / 3 \times \mathrm{BKA} \\
1 / 3 \mathrm{BKB}=1 / 3 \times \mathrm{BKB}
\end{gathered}
$$

\section{Menghitung Master Production Schedule} sebagai berikut:

a. Tahap pertama

Menentukan besarnya kapasitas atau kecepatan operasi yang diinginkan. Perencanaan ini biasanya dilakukan pada tingkat agregat (dengan meminimalkan total biaya produksi untuk keseluruhan produk yang dibuat) sesuai dengan kapasitas yang dimiliki.Rencana kapasitas secara agregat ini terutama diarahkan pada unit-unit yang 
dianggap sebagai titik kritis atau Potensial Bottle Neck.

\section{b. Tahap kedua}

Menentukan jumlah total tenaga kerja yang dibutuhkan disetiap periode. Jumlah mesin, dan jumlah shift kerja yang diperlukan untuk penjadwalan.Pada tahap ini juga dilakukan perencanaan jumlah persediaan secara agregat. Dalam hal ini, suatu perencanaan kebutuhan akan persediaan pengaman untuk memelihara service level kepada konsumen lazim dilakukan. Jumlah persediaan pengaman sangat tergantung pada jenis barang dan kebijakan perusahaan.

\section{HASIL DAN PEMBAHASAN}

Waktu Proses Per-operasi Kerja

Beikut ini merupakan data permintaan single bed 2018:

Tabel 1.1

Data Permintaan Single Bed
\begin{tabular}{|l|c|}
\hline Periode & Permintaan \\
\hline Januari & 1820 \\
\hline Februari & 1690 \\
\hline Maret & 1690 \\
\hline April & 1690 \\
\hline Mei & 1690 \\
\hline Juni & 1820 \\
\hline Juli & 1820 \\
\hline Agustus & 1690 \\
\hline September & 1690 \\
\hline Oktober & 1690 \\
\hline November & 1690 \\
\hline Desember & 1950 \\
\hline
\end{tabular}

Dari tabel diatas data permintaan Single bed selama 12 periode dari bulan januari sampai bulan desember 2018 .

\section{Pemilihan Metode Peramalan}

Data yang dipakai adalah data permintaan single bed 2018 dengan menentukan peramalan dari metode linier dan siklis :

\section{Metode Linier}

Peramalan yang dilakukan dengan metode linier digunakan jika data historis/masa lalu yang ada tersebut memiliki fluktuasi berupa garis lurus sepanjang periode waktu tertentu. Fungsi peramalan dengan metode ini adalah :

$$
y^{\prime}=a+b t
$$

Tabel 1.2

Rekap Galat Metode Peramalan Linier

\begin{tabular}{|c|c|c|c|c|}
\hline $\mathrm{t}$ & $\mathrm{y}$ & $\mathrm{y}^{\prime}$ & $\mathrm{e}=\mathrm{y}^{\prime} \mathrm{y}^{\prime}$ & $\mathrm{e} 2$ \\
\hline 1 & 1820 & 1716.667 & 103.33 & 10677.78 \\
\hline 2 & 1690 & 1716.667 & -26.67 & 711.11 \\
\hline 3 & 1690 & 1716.667 & -26.67 & 711.11 \\
\hline 4 & 1690 & 1716.667 & -26.67 & 711.11 \\
\hline 5 & 1690 & 1716.667 & -26.67 & 711.11 \\
\hline 6 & 1820 & 1716.667 & 103.33 & 10677.78 \\
\hline 7 & 1820 & 1716.667 & 103.33 & 10677.78 \\
\hline 8 & 1690 & 1716.667 & -26.67 & 711.11 \\
\hline 9 & 1690 & 1716.667 & -26.67 & 711.11 \\
\hline 10 & 1690 & 1716.667 & -26.67 & 711.11 \\
\hline 11 & 1690 & 1716.667 & -26.67 & 711.11 \\
\hline 12 & 1950 & 1716.667 & 233.33 & 54444.44 \\
\hline Total & 20930 & 20600 & 330.00 & 92166.67 \\
\hline \multicolumn{5}{|c}{ SEE } \\
\hline \multicolumn{5}{|c|}{96.00347} \\
\hline
\end{tabular}

$$
S E E=\sqrt{\frac{\sum\left(y-y^{\prime}\right)^{2}}{n-f}}=96,00347
$$

\section{Metode Siklis}

Berikut ini tabel rekap galat dari metode siklis dapat dilihat sebagai berikut :

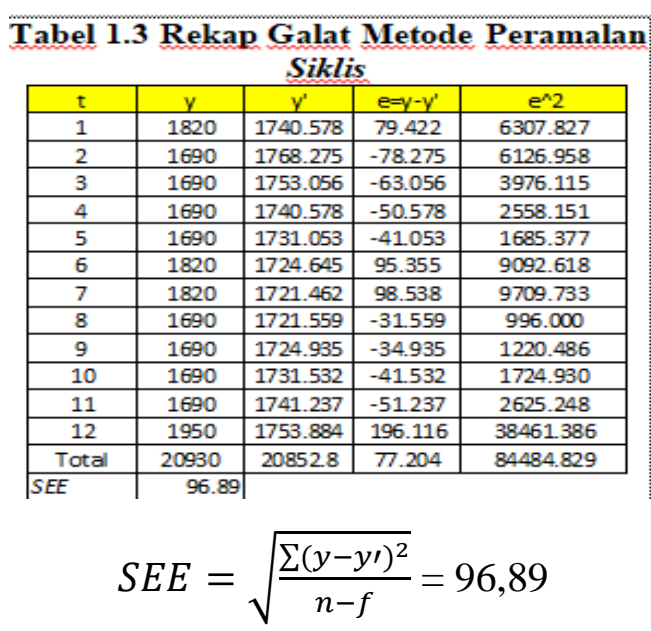

Pengolahan data awal yaitu menghitung nilai SEE dari 2 metode peramalan linier dan siklis. Nilai SEE metode linier yang dipakai untuk meramalkan permintaan untuk periode selanjutnya karena tingkat kesalahan nya terkecil

\section{Peramalan dengan Metode Terbaik Untuk 12 Periode ke Depan}

Metode peramalan terbaik yaitu peramalan yang memperoleh hasil SEE terkecil, dalam penelitian ini metode peramalan yang memperoleh SEE terkecil yaitu metode peramalan linier 
Tabel 1.4

Hasil Metode Peramalan Terbaik (Metode Peramalan Linier)

\begin{tabular}{|c|c|c|}
\hline \multirow{2}{*}{ No } & \multirow{2}{*}{ Periode } & Ramalan Produksi \\
\cline { 3 - 3 } & & (Unit) \\
\hline 1 & 13 & 1777 \\
\hline 2 & 14 & 1782 \\
\hline 3 & 15 & 1787 \\
\hline 4 & 16 & 1792 \\
\hline 5 & 17 & 1797 \\
\hline 6 & 18 & 1802 \\
\hline 7 & 19 & 1807 \\
\hline 8 & 20 & 1812 \\
\hline 9 & 21 & 1817 \\
\hline 10 & 22 & 1822 \\
\hline 11 & 23 & 1827 \\
\hline 12 & 24 & 1832 \\
\hline
\end{tabular}

Pada tabel hasil metode peramalan diatas yang akan dipakai untuk menghitung perencanaan kebutuahan material dari single bed untuk periode 12 bulan kedepan.

\section{Bill Of Material}

Berikut ini data Bill Of Material dan gambar dari struktur produk kasur single bed dapat kita lihat sebagai berikut :

Tabel 1.5

Bill Of Material Single Bed

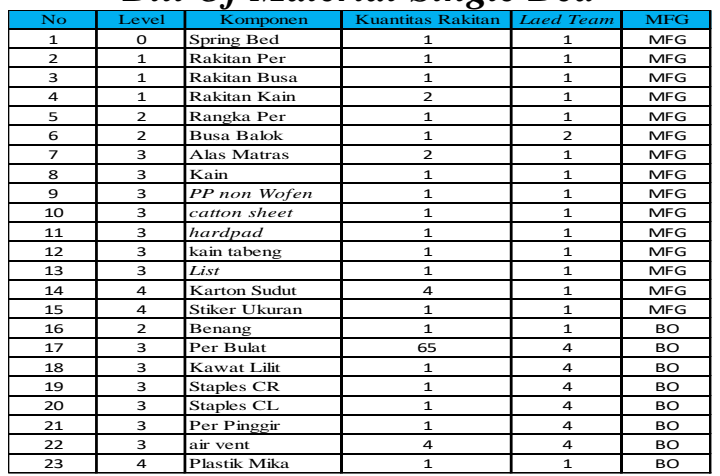

Perhitungan Material Requirement Planning untuk Komponen MFG

Pada perhitungan komponen MFG akan dipakai rumus Material Requirement Planning sebagai berikut ini :

a. Gross Requirement (GR)

1) Untuk level $0=$ MPS

2) Untuk level $1=$ dari PORel level $0 \times$ jumlah unit

3) Untuk level $2=$ dari PORel level $1 \mathrm{x}$ jumlah unit

4) Untuk level $n=$ dari PORel level $n-1 \times$ jumlah unit b. Project on Hand $(\mathrm{POH})=$ Current inventory - Allocated

c. Net Requirement $(N R)=N R t=$ Max \{0, GRt-POHt-1-SRt\}

d. Planned Order Receipt (POREC) $=N R$

e. Planned Order Release (POREL) $=$ POREC

Perhitungan MRP untuk Komponen MFG Level 0

Pada perhitungan komponen MFG akan dipakai rumus Material Requirement Planning sebagai berikut ini :

Tabel 1.6

Data Perhitungan MRP Rakitan Spring

Bed

\begin{tabular}{|c|c|c|c|c|c|c|c|c|c|c|c|c|c|}
\hline \multicolumn{2}{|c|}{$\begin{array}{l}\text { Nama Konononer } \\
\text { SSing beed }\end{array}$} & & Cl & & & dTime & & & \multicolumn{2}{|c|}{ Letrel } & & \\
\hline Periodere & & 1 & 2 & 3 & 4 & j & 6 & 1 & 8 & $g$ & 10 & 11 & 11 \\
\hline SI & & 177 & 1782 & 1787 & 1792 & 1997 & 1802 & 1007 & 1812 & 187 & 1882 & 1887 & 1882 \\
\hline & & 0 & & & & & & & & & & & \\
\hline $\mathrm{POH}$ & 0 & 0 & 0 & 0 & 0 & 0 & 0 & 0 & 0 & 0 & 0 & 0 & 0 \\
\hline tim & & 1777 & 1782 & 1787 & 1792 & 1997 & 1802 & 1807 & 1812 & 1817 & 1802 & 1887 & 1.82 \\
\hline PDOREC & & 1777 & 1782 & 1787 & 1792 & 1997 & 1802 & 1007 & 1812 & 1817 & 1822 & 1807 & 1882 \\
\hline POREL & 1977 & 1978 & 1787 & 1992 & 1997 & 1802 & 1807 & 1812 & 1817 & 1802 & 1887] & 1832 & \\
\hline
\end{tabular}

Pada level 0 pada rakitan spring bed data dari MPS kita masukkan ke gross requirments dari periode 1- 12. Dan project on hand nya 0 , jumlah komponen per unit nya 1 . Dan plan order release nya 232 dimasukkan ke periode 0 disesuaikan dengan lead timenya.

\section{Perhitungan MRP untuk Komponen MFG Level 1}

Berikut ini perhitungan MRP untuk komponen rakitan pegas dapat dilihat pada tabel sebagai berikut : 
Tabel 1.7

Data Perhitungan MRP Rakitan Pegas

\begin{tabular}{|c|c|c|c|c|c|c|c|c|c|c|c|c|c|}
\hline Romonomen & & & & & & & & & & Ahomanc & & & \\
\hline Periode & . & 0 & 1 & ! & 3 & 4 & $j$ & 6 & 1 & 8 & 9 & 10 & 11 \\
\hline GS & & 177 & 1978 & 1178 & 199. & 1997 & 1002 & 1907 & 1812 & 187 & 1802 & 187 & 1802 \\
\hline SR & & 0 & & & & & & & & & & & \\
\hline POH & 0 & 0 & 0 & 0 & 0 & 0 & 0 & 0 & 0 & 0 & 0 & 0 & 0 \\
\hline $\mathbb{N}$ & & 1777 & 1782 & 1.178 & 1792 & 1997 & 1002 & 1807 & 1812 & 1817 & 1802 & 1872] & 1882 \\
\hline POREC & & 1777 & 1702 & 1787 & 199. & 1997 & 1002 & 1.807 & 1812 & 1817 & 1802 & 1807] & 1.832 \\
\hline POREL & 1777 & 1782 & 1.178 & 1992 & 1997 & 1002 & 1807 & 1812 & 1807 & 1802 & 1807 & 1832 & \\
\hline
\end{tabular}

Pada level 1 pada rakitan pegas data dari MPS kita masukkan ke gross requirements dengan perhitungan level $1=$ porel level $0 \mathrm{x}$ jumlah unit dengan nilai MPS $=1777$ dari periode 0 - 11. Dan project on hand nya 0 , jumlah komponen per unit nya 1. Dan plan order release nya 1777 dimasukkan ke periode -1 disesuaikan dengan lead timenya.

\section{Perhitungan MRP untuk Komponen MFG Level 3}

Berikut ini perhitungan MRP untuk komponen alas matras dapat dilihat pada tabel sebagai berikut :

\section{Tabel 1.8}

Data Perhitungan MRP Alas Matras

\begin{tabular}{|c|c|c|c|c|c|c|c|c|c|c|c|c|c|}
\hline 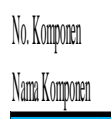 & & & & & Whatedll & & & & & & & & \\
\hline Peinde & 3 & 2 & $\frac{1}{1}$ & I & 1 & ? & 3 & 4 & & & & 8 & 9 \\
\hline 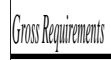 & & 354 & 3504 & 354 & 3894 & 94 & 3004 & 364 & & & & 3504 & 3604 \\
\hline 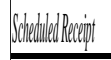 & & 0 & & & & & & & & & & & \\
\hline 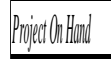 & 10 & 10 & 10 & 10 & $\mathbb{1}$ & 0 & 10 & 10 & & 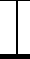 & & 10 & 10 \\
\hline 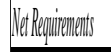 & & 344 & 3554 & 364 & 3574 & 4 & 5904 & 304 & & & & 354 & 3504 \\
\hline Pla Ohaterenept & & 344 & 354 & 364 & 3574 & 4 & 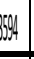 & 304 & & & & 354 & 364 \\
\hline 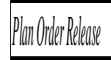 & 354 & 3594 & 564 & 7 & 3584 & 194 & 6004 & 604 & & & & 3604 & \\
\hline
\end{tabular}

Pada level 3 pada alas matras data dari MPS kita masukkan ke gross requirments dengan perhitungan level $3=$ porel level $3-1 \mathrm{x}$ jumlah unit dengan nilai $=1777 \times 2=3554$ dengan nilai MPS $=3554$ dari periode $-2-9$. Dan project on hand nya dengan perhitungan current inventory - allocated inventory = $140-130=10$, dan Net requirement dengan perhitungan gross requirments- project on hand - schedule receipt $=3554-10-0=$ 3544 jumlah komponen per unit nya 2. Dan plan order release nya 3544 dimasukkan ke periode -3 disesuaikan dengan lead timenya.

\section{Perhitungan Material Requirement Planning untuk Komponen BO}

Pada perhitungan untuk komponen BO ini adalah kita akan menghitung Periode Order Quantyty ( POQ ), biaya pemesanan, biaya penyimpanan dan total biaya dari sebuah komponen yang dibutuhkan dalam proses assembling setelah itu baru kita lakukan pengolahan data dengan menggunakan motode Material Requirement Pllaning

\section{Perhitungan MRP untuk Komponen BO Benang Level 2}

Berikut ini perhitungan MRP untuk komponen Benang dapat dilihat pada tabel sebagai berikut :

\section{Tabel 1.9}

Data Perhitungan Requirement Benang

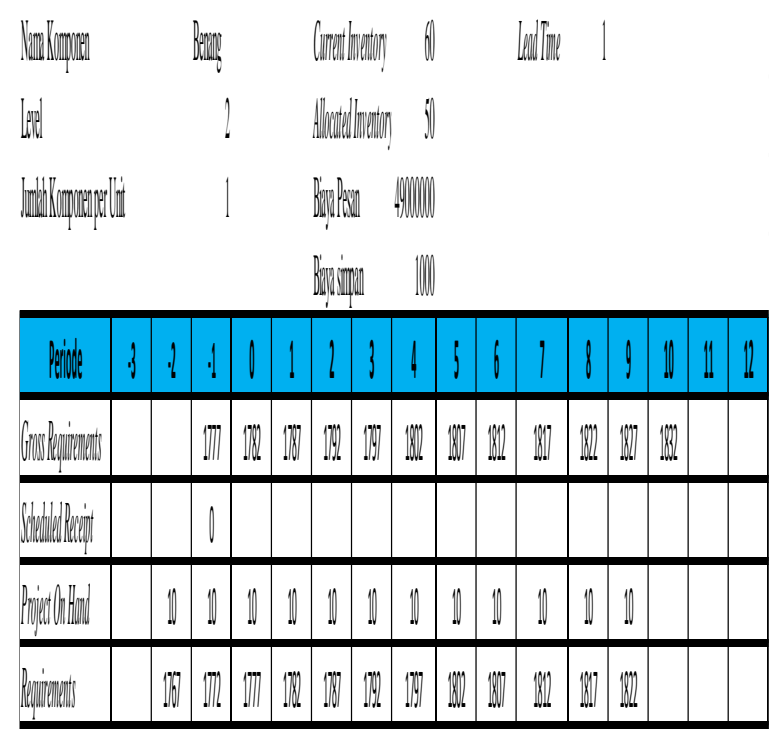

Pada level 2 pada komponen BO benang data dari MPS kita masukkan ke gross requirments dengan perhitungan level $2=$ porel level $1 \mathrm{x}$ jumlah unit dengan nilai MPS $=1777$ dari periode -1 - 10. Dan project on hand nya dengan perhitungan current inventory - allocated inventory $=60-50=$ 10, jumlah komponen per unit nya 1 . Dan 
Requirement dengan perhitungan gross requirments- project on hand- schedule receipt $=1777-10-0=1766$ pada periode -2 - 9. Data perhitungan Requirement yang akan dingunakan untuk mencari MRP pada komponen benang. Pada tabel diatas biaya pesan dari benang adalah Rp. 49.000.000 untuk satu kali pemesanan dalam satu bulan dan biaya simpannya dalah Rp 1000 per hari.

Berikut ini tabel dari POQ dan EOI untuk komponen benang dapat dilihat sebagai berikut :

Tabel 1.10

POQ untuk komponen Benang

\begin{tabular}{|c|c|}
\hline Periode & Requirements \\
\hline-2 & 1767 \\
\hline-1 & 1772 \\
\hline 0 & 1777 \\
\hline 1 & 1782 \\
\hline 2 & 1787 \\
\hline 3 & 1792 \\
\hline 4 & 1797 \\
\hline 5 & 1802 \\
\hline 6 & 1807 \\
\hline 7 & 1812 \\
\hline 8 & 1817 \\
\hline 9 & 1822 \\
\hline Total & 21534 \\
\hline R & 1794.5 \\
\hline EOI & 7.39 \\
\hline
\end{tabular}

Mencari total di dapat dari hasil dari periode -2 sampai 9 dijumlahkan dan didapat hasil nya $=21534$.

Untuk mencari $\mathrm{R}$ didapat dari = nilai rata rata ( $\mathrm{R} / 12)$ dan hasilnya 1794,5.

Untuk mencari EOI = Hasil kuadrat $(2 \mathrm{x}$ 49.000.000 $) /(1794,5 \times 1000)=7,39$

Berikut ini pengolahan data untuk perhitungan Material requirement Planning dari komponen benang dapat dilihat pada tabel berikut :

Tabel 1.11

Data Perhitungan MRP Benang

\begin{tabular}{|c|c|c|c|c|c|c|c|c|c|c|c|c|c|}
\hline Paide & 4 & . & 1 & $!$ & V & & & 3 & 4 & $f$ & 6 & & \\
\hline 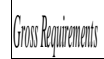 & & & 108 & $\mathbb{1 7 \pi}$ & III & 1082 & 187 & 192 & 197 & Bu & $(18)$ & & \\
\hline 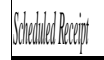 & & & 0 & & & & & & & & & & \\
\hline Priventhent & & 10 & 10 & 10 & $\mathbb{D}$ & 10 & $\mathbb{1}$ & 10 & $\mathbb{1}$ & 10 & $\mathbb{1}$ & & 0 \\
\hline Wherimanenth & & & 177 & 176. & IVI & 114 & III & & |lol & 199. & 199 & & 018 \\
\hline 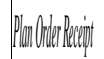 & & & $\mid 17]$ & 176 & 1010 & $1 / 1 / 1$ & (I7] & 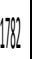 & 181 & $19 \%$ & $|99|$ & & 01.1 \\
\hline 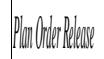 & & 137 & 170 & 186 & & & 10 & & & 199 & 1021 & 011 & 11. \\
\hline
\end{tabular}

Pada level 2 pada komponen benang data dari Requirement kita masukkan ke gross requirments dengan nilai MPS $=1767$ dari periode -2 - 9. Dan project on hand nya dengan perhitungan current inventory allocated inventory $=60-50=10$, jumlah komponen per unit nya 1. Dan Net requirement dengan perhitungan gross requirments- project on hand- schedule receipt $=1767-10-0=1756$. Dan plan order release nya 1756 dimasukkan ke periode -3 karena disesuaikan dengan lead timenya.

\section{Perhitungan MRP untuk Komponen BO Kawat Lawat Level 3}

Berikut ini perhitungan MRP untuk komponen kawat lilit dapat dilihat pada tabel sebagai berikut :

Tabel 1.12

Data Perhitungan Requirement Kawat

\begin{tabular}{|c|c|c|c|c|c|c|c|c|c|c|c|c|c|}
\hline Mo Konponen & & & & & & & & & & & A Time & 4 & \\
\hline lanan Komponen & & & Garrat Li. & & & & & & & & & & \\
\hline Lerel & & & & & & $e x$ & & M & & & & & \\
\hline 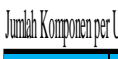 & & & & & & inim & & 100 & & & & & \\
\hline Peiolde & 3 & 2 & 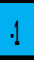 & 0 & 1 & 1 & 3 & 4 & $j$ & 6 & 1 & 8 & 9 \\
\hline 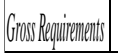 & & 1777 & 1782 & 1787 & 1992 & 199 & 802. & 1007 & 1812 & 1817 & 1802 & 1887 & 1832 \\
\hline 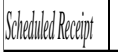 & & 0 & & & & & & & & & & & \\
\hline wivet On Hand & 5 & 5 & 5 & 5 & 5 & 5 & 5 & 5 & 5 & 5 & 5 & 5 & \\
\hline intrencens & 1772 & 1777 & 1782 & 1787 & 1992 & 199 & 1002 & 1807 & 1812 & 1817 & 1802 & 1807 & \\
\hline
\end{tabular}

Pada level 3 pada komponen BO kawat lilit data dari MPS kita masukkan ke gross requirments dengan perhitungan level $3=$ porel level $\mathrm{n}-1 \mathrm{x}$ jumlah unit dengan nilai MPS $=1777$ dari periode -2 - 9. Dan project on hand nya dengan perhitungan current inventory - allocated inventory $=10-5=5$, jumlah komponen per unit nya 1. Dan Requirement dengan perhitungan gross requirments- project on hand- schedule receipt $=1777-5-0=1772$ pada periode $3-8$. 
Tabel 1.13

POQ untuk komponen Kawat Lilit

\begin{tabular}{|c|c|}
\hline Periode & Requirements \\
\hline-3 & 1772 \\
\hline-2 & 1777 \\
\hline-1 & 1782 \\
\hline 0 & 1787 \\
\hline 1 & 1792 \\
\hline 2 & 1797 \\
\hline 3 & 1802 \\
\hline 4 & 1807 \\
\hline 5 & 1812 \\
\hline 6 & 1817 \\
\hline 7 & 1822 \\
\hline 8 & 1827 \\
\hline Total & 21594 \\
\hline$R$ & 1799.5 \\
\hline EOI & 25.19 \\
\hline
\end{tabular}

Mencari total di dapat dari hasil dari periode -3 sampai 8 dijumlahkan dan didapat hasil nya $=21594$.

Untuk mencari $\mathrm{R}$ didapat dari = nilai rata rata ( R/12) dan hasilnya 1799,5.

Untuk mencari EOI = Hasil kuadrat ( $2 \mathrm{x}$ $571.000 .000) /(1799,5 \times 1000)=25,19$.

Berikut ini pengolahan data untuk perhitungan Material requirement Planning dari kawat lilit dapat dilihat pada tabel berikut :

\section{Tabel 1.14}

Data Perhitungan MRP Kawat

\begin{tabular}{|c|c|c|c|c|c|c|c|c|c|c|c|c|c|c|c|}
\hline Priode & \begin{tabular}{l|l}
.1 & 6 \\
\end{tabular} & $\begin{array}{l}6.5 \\
6.5\end{array}$ & 4 & 3 & 2 & 4 & 0 & 1 & ? & 3 & 4 & 5 & & 8 & \\
\hline 169 & & & & 1772 & 1777 & 1882 & 187 & 1992 & 1997 & 1802 & 1807 & & & 1827 & \\
\hline SR & & & & 0 & & & & & & & & & & & \\
\hline POH & & & 5 & 5 & 5 & 5 & 5 & 5 & 5 & 5 & 5 & 5 & & 5 & \\
\hline $\mathbb{N R}$ & & & & 1567 & 1772 & 1777 & 1882 & 187 & 1992 & 1997 & 1002 & 1807 & 821218. & 182 & \\
\hline PDREC & & & & 1167 & 1772 & 1777 & 1782 & 187 & 1992 & 1997 & 1002 & 1807 & 81218 & 188 & \\
\hline POREL & \begin{tabular}{|l|l|l|}
1176 \\
\end{tabular} & 4772 1977 & 1782. & 1187 & 1992 & 1997 & 1802 & 1807 & 2 & 1897 & 1802 & & & & \\
\hline
\end{tabular}

Pada level 3 pada komponen kawat lilit data dari Requirement kita masukkan ke gross requirments dengan nilai MPS $=1772$ dari periode -3 - 8. Dan project on hand nya dengan perhitungan current inventory allocated inventory $=10-5=5$, jumlah komponen per unit nya 1. Dan Net requirement dengan perhitungan gross requirments- project on hand- schedule receipt $=1772-5-0=1767$. Dan plan order release nya 1767 dimasukkan ke periode -7 karena disesuaikan dengan lead timenya adalah 4.

\section{Perhitungan MRP untuk Komponen BO Plastik Mika Level 4}

Berikut ini perhitungan MRP untuk komponen plastic mika dapat dilihat pada tabel sebagai berikut :

Tabel 1.15

Data Requirement Plastik Mika

\begin{tabular}{|c|c|c|c|c|c|c|c|c|c|c|c|c|c|c|}
\hline Peride & 6 & 5 & 4 & 3 & ? & ! & 0 & & & 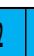 & 3 & 4 & 5 & 6 \\
\hline Gross Regrimentins & & & 17212 & 1977 & 1732 & 1137 & 174 & & & 52 & 157 & 1762 & 1667 & 1772 \\
\hline Shreduled Reciont & & & 0 & & & & & & & & & & & \\
\hline Provert On Hend & & 55 & 55 & 55 & 55 & 55 & 55 & & & 55 & 55 & 55 & 55 & 55 \\
\hline Net Reanivementis & & & 1567 & 1672 & 1677 & 1682 & 168 & & & 697 & 102 & 107 & 1712 & 1717 \\
\hline Plan Orider Reciont & & & 1567 & 1672 & 1677 & 158 & 1680 & & & 697 & 102 & 1007 & 1712 & 1917 \\
\hline Plan Orider Relense & 1677 & 1802 & 1.67 & 1692 & 1697 & 100 & 170 & & & 717 & & & & \\
\hline
\end{tabular}

\section{KESIMPULAN}

Berdasarkan perhitungan yang telah dilakukan, dapat disimpulkan bahwa dari 2 metode peramalan (metode linear dan metode siklis) metode terbaik dipilih adalah metode linier karena memiliki nilai SEE yang terkecil yaitu sebesar 96,0034. Berikut ini hasil peramalan permintaan single bed untuk 12 periode kedepan dari bulan januari sampai desember : pada bulan januari permintaan 1777, februari sebesar 1782 , maret sebesar 1787, april sebesar 1792, mei sebesar 1797, juni sebesar 1802, juli sebesar 1807, agustus sebesar 1812, september sebesar 1817, oktober sebesar 1822, november sebesar 1827 dan desember sebesar 1832 dan Pada perencanaan kebutuhan bahan baku dengan menggunakan metode MRP ini dengan menentukan nilai MFG dan BO dengan nilai masing masing rilis pesanan yang direncanakan pada Spring bedsebesar 1777 unit pada periode Januari, Rakitan per sebesar 1777 unit pada periode Januari, Rakitan busa sebesar 1777 unit pada periode Januari, Rakitan kain sebesar 3554 unit pada periode Januari, Rangka per 1777 unit pada periode Februari, Busa per 1776 unit pada periode Maret, Alas matras 3544 unit pada periode Maret, Rakitan kain 1775 unit pada periode Maret, PP non Wofen 1757 unit pada periode Maret, Catton Sheet 
1767 unit pada periode Maret, Hardpad 1767 unit pada periode Maret, Kain Tabeng 1772 unit pada periode Maret, list 1767 unit pada periode Maret, Karton Sudut 7068 unit pada periode April, Stiker Ukuran 1762 unit pada periode April, Benang 1757 unit pada periode Maret, Per bulat 114855 unit pada periode Juli, Kawat lilit 1767 unit pada periode Juli, Steples CR 1757 unit pada periode Juli, Steples CL 1757 unit pada periode Juli, Per pinggir 1697 unit pada periode Juli, Air vent 7028 unit pada periode Juli dan Plastik mika 1667unit pada periode Agustus.

\section{DAFTAR PUSTAKA}

Assauri, S. Manajemen Produksi dan Perencanaan dan Pengendalian Produksi. Lembaga Penerbitan Fakultas Ekonomi Universitas Indonesia, Jakarta. 2008

Ervil Riko, Arbi Yaumal, Murad, Ernita Tri, Wedyawati Veni .Buku Panduan Penulisan Dan Ujian Skripsi, STTIND Padang. 2019.

Ervil Riko, Numayuni Dela.Penjadwalan Produksi Dengan Metode Campbell Dudek Smith (CDS) Untuk Meminimumkan Total Waktu Produksi,Jurnal Saints dan TeknologiSTTIND Padang. 18 (2), 4549, 2018.

Ervil Riko, Rosalina Mela.Estimasi Permintaan Air Minum Dalam Kemasan AYIA CUP 240 ML, Jurnal Pendidikan Teknologi Kejuruan 2 (2), 67-73,2019

Fajar Rahmad. Penerapan Material Requriment Palnning Dalam Perencanaan Persedian Bahan Baku Produk Botol Dk 8211 B. Universitas Negri Surabaya. Jurnal Volume 3 Nomor 1 Tahun 2016.

Irawan Ade, Syaichu Achmad. Pengendalian Persediaan Bahan Baku Dengan Metode Material Requirement Palnning Pad Apt Semen Indonesia (Persero), Tbk.Program Teknik Industri. Journal
Knowledge Industrial Engineering Volume 4 Nomor 1 Tahun 2017.

Idris Iswandi. Analisis Perencanaan Kebutuhan Bahan Baku Dengan Menggunakan Material Requirements Planning. Program Teknik Industri, Politeknik Lp31 Medan. Jurnal Teknovasi Volume 02 Nomor 1 Tahun 2015.

Sulistiyowati Wiwik, Sungkono Adi.

Perencanaan Dan Pengendalian Bahan Baku Untuk Meningkatkan Efesiensi Produksi Dengan Metode Material Requirement Palnning Dan Analytical Hierarchy Process Di Pt. $\boldsymbol{X y z}$.Program Studi Teknik Industri, Unuversitas Muhammadiyah Sidoarjo. Jurlan Industri Volume 14 Nomor 1 Tahun 2016.

Syaichu Achmad, Wahyuni Asvin. Perencanaan Persediaan Bahan Baku Dengan Menggunakan Metode Requrment Planning Produk Kacang Shanghai Pada Perusahaan Gangsar.Program Tenik Industri. Jurnal Spectrum Industri Volume 13 No 2 Tahun 2015.

Handoko, T. Dasar - Dasar Manajemen

Produksi dan Operasi, Edisi Pertama, BPFE : Yogyakarta.2004.

Nasution, Arman Hakim. Perencanaan dan Pengendalian Produksi. Guna Widya. Surabaya. 2003. 